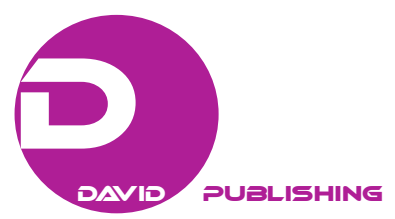

\title{
Epistemic Inquiry into African (Igbo) Philosophy of Death
}

\author{
Raphael Olisa Maduabuchi, Stephen Chijioke Chukwujekwu \\ Chukwuemeka Odumegwu Ojukwu University, Igbariam Campus, Anambra State, Nigeria
}

\begin{abstract}
This paper sought to examine Igbo philosophy of death as an essential feature for authentic human existence in Africa. Death is a mystery which defies human understanding. No wonder, existentialist philosophers conceive death as the facticity of human existence. Different cultures have undertaken to unravel the mystery of death. Hence, African nay Igbo conceives death as a transition of human beings from this physical world of the living to the world of the spirit. The invisible world of the spirit is a place where our revered ancestors live. The second burial rites are performed to gravitate the dead to ancestral world of spirit. African metaphysical assumptions of death and life after death are therefore subjected to critical examination.
\end{abstract}

Keywords: Igbo, Africans, ancestors, spiritual, physical and existence

\section{Introduction}

Death is a common phenomenon which everybody expects in anticipation. Scholars conceive death differently. On this note, death is defined as end of life; the state of being dead (Hornby, 2011, p. 298). The state of being dead implies that one is no longer alive. Death can be sudden, violent and peaceful. In some cases, it comes at a moment when one least expects it. Anybody can die at any moment.

Philosophers have undertaken to unravel the mystery behind death. Jean Paul Sartre conceived death as a meaningless absurdity which removes all meaning from human existence (Omoregbe, 1991, p. 51). Death, sickness, disease, disappointment, sorrow, man's powerlessness in the face of nature, constitutes the facticity of human existence. Existentialists conceive the facticity of human existence as the limiting factors of human existence. Among the main features of the facticity of human existence is man's finitude, that is, that man is a limited being. Thus, death expresses man's limitation in this physical world.

Death is one of the prominent themes of existentialism. Existentialism is a 20th century philosophical movement which proclaims the subjective selfhood of individual authenticity. Hence, Martin Heidegger viewed life as a progressive journey to death which confers on human existence its individuality, uniqueness and meaning (Heidegger, 1973, p. 307). It implies that man is old enough to die as soon as he/she is born. In Heideggerian sense, death is the final term in a series which by reverse flow permeates and influences the whole series. It is like the final chord of melody which gives melody its meaning. On this note, P. Koestenbaum expressed that the person who is aware of his death and the consequent limit of his time on earth will thereby concentrate on essentials (Koestenbaun, 1964). Thus, man is prompted to get immediately to the point of his life.

Olisa Raphael Maduabuchi, Ph.D.(Nig), Department of Philosophy, Chukwuemeka Odumegwu Ojukwu University, Igbariam Campus, Anambra State, Nigeria.

Rev. Fr. Stephen Chijioke Chukwujekwu, Ph.D., Department of Philosophy Chukwuemeka Odumegwu Ojukwu University, Igbariam Campus, Anambra State, Nigeria. 
However, the episode of death is accompanied by deep sense of loss and grief. Death is an inescapable fact of human existence which is experienced in every culture. Different cultures conceive death in different ways. African conception of death may not be quite different from the common conception of death. Good death in Igbo culture is a meaningful part of earthly sojourn. A proper exposition of Igbo concept of death will help to portray death as the final term in life series which remains as an integral part of life.

\section{Igbo Conception of Death}

Life, death and after life are closely connected in Igbo traditional thought. Igbos conceive death as a transition of human beings from physical world to the spiritual world. According to Aja (2001), the spirit world in African cosmology is the abode of the spirits or ancestors (Ala Mmuo). The dead continues to live in the spirit world, receiving a new form of life with enhanced power to secure good fortune and protection for family as ancestor. But,the dead does not gravitate to his/her destination in the spirit world until his/her second burial rites are performed (Ogbukagu, 1997, p. 219). Since the goal of life is to become an ancestor after death, every person who dies must be given a befitting burial rite. If this is not done, the dead may become a wondering ghost unable to live properly after death.

One is expected to die at a ripe old age. The death of children is regarded as a particularly grievous evil event, and many people give special names to their children to try to ward off the reoccurrence of untimely death e.g. Onwusorom (death avoid me), Onwurah (death leave me), Onwuegbuna (death do not kill) etc. In general, death is not considered as a natural event. Thus, death tends to be seen as caused by some external forces such as witches, spirits or curse (Mbiti, 1975, p. 118). The incidence of untimely death is very painful for the Igbos because the person has not fulfilled his destiny on earth.

Nevertheless, there are certain deaths that are totally abhorred and not honoured. The restrictions of giving normal burial and second burial rites to deceased person are governed chiefly by considerations of birth; rank and cause of death (Basden 1982, p. 114). In the olden days, death accruing from some disease like leprosy and small pox are thrown into evil forest even before the actual death. Out-cast (osu) and witches receive scant attention. Witches are banished from the town. Out-cast are seen as useless people who travel from shrine to shrine taking food items. Their corpse is thrown into the evil forest.

In the same vein, a woman giving birth to twins in lgbo culture is an abomination in the olden days. Twins are carried alive in a pot and dropped at the evil forest at the mercy of carnivorous animals to die. People suffering from abdominal distention (onye-tolu-afo) are isolated from others and abandoned in a wilderness to die. In addition, suicide death is abominable to the whole community. On this note, the corpse of suicide victims is treated with disdain (Maduabuchi, 2009, pp. 46-48). The body is thrown into evil forest. In some community, a six feet pit is dug at the scene where the offence is perpetrated. The traditional chief priest of Nri kingdom popularly known as "Aka Nri" (dwarfs) will be invited to cut the rope where the body will fall into the pit accompanied by some propitiatory sacrifice. In some part of Igbo land, the rope and the tree which the act is perpetrated are cut down subsequently. It is believed that any physical contact with the body of the victim is believed to have a disastrous effect in the society.

\section{Second Burial or Funeral Rite}

The dead body is laid to the mother earth to rest. Igbos believe that unless a dead person is accorded befitting funeral rites, he/she cannot reach the spirit world (Ala Mmuo). According to Donnel (1931), when a 
person dies, his soul or spirit wanders till it is received in the blessed memory of his forebears on condition that the relations on earth celebrate the funeral ceremonies. The spirit of the dead is not happy to be homeless. They will continue to haunt, disturb and inflict vengeance on the relatives for their negligence to perform funeral ceremonies. Moreover, the calamities that sometimes fall on some persons or families are attributed to wrath from such restless departed relatives due to the negligence on the part of affected persons to execute the second burial rites of dead relatives to give them peace and opportunities to interact with their kith and kin in the spirit world (Ogbukagu, 1997, p. 231). In the light of the above, this belief in some places require that the person must have been a good man on earth or at least that a cleansing rite be performed over the corpse before burial.

The second burial rites of non titled man (Okolo) are different from titled men (Nze-na-ozo). On the other hand, the preliminary ceremonies seem to be the same. Hence, the kindred men are invited to the dead person's compound and presented with four kola nut and she-goat for non titled men, and eight kola nuts and a cow (calf) for the titled men world (Ogbukagu, 1997, p. 232). Objects of sacrifice are splitted into two halves with a matchet. However, the goat or cow is killed and shared among the kindred men with its rib (ose) sent to the maternal grandfather of the deceased. Then four kola nuts are presented to all representatives of the town for the proposed second burial rites and other preparations are made towards the second burial.

On the evening of the eve for the second burial ceremonies, a gunshot is released by the deceased family signaling the general public of commencement of the rites the following day. This event is geared to signal the spirit of a departed of the final arrangement for his or her direct gravitation into the spirit world for union with his already departed kin world (Ogbukagu, 1997, p. 233). A cock is suspended in the morning of the ceremonies head down on a fairly long pole at the far end of the compound tied with fresh palm fronds (omu). Then, arrangement is made for preparation of foods and procurement of drinks for entertainments.

A gun shot is fired at 12.00 noon notifying the in-laws, friends and well wishers of time for reception of visitors. Friends, in-laws and well wishers of deceased family come with gifts to the bereaved family. The family will receive and entertain them with food and drinks. Daughters of the kindred (umu okpu) are entertained as well. They express their kind gestures in form of song which serves as indication that the second burial was successful. The canon shots released during the funeral ceremonies are meant to accompany the dead person into the spirit world.

The second burial rites of deceased titled men are more sophiscated and expensive. In some cases, the titled men reserved sufficient money, gun powder and other perishable items for execution of their funeral rites so that their second burial rites will not be delayed.

\section{Life After Death}

There are two worlds in Igbo cosmology: the visible world of the living and the invisible world of the spirit. The visible world of the living and the invisible world of the spirit dovetail and interact mutually (Aja, 2001, p. 52). Ancestors are living in the spirit world. They are the living dead who took active interest in human kinship. Ancestral spirits make endless journey back into the visible world.

Hence, Igbo family is not made of only those who are still living in fresh. The ancestors are felt to be present, watching over the household, directly concerned in all the affairs of the family and property, giving abundant harvests and fertility (Arinze, 1967, p. 19). Igbos worship the cult of ancestors because the ancestral spirits are conceived as intermediaries who relay the prayers to God (chiukwu). Ancestors can serve as intermediaries between God and people and can communicate with the living through various means such as 
dreams, possession and divination (Magesa, 1997, pp. 78-81). Divination is performed by a diviner.

Igbos make sacrifice to their ancestors to averts danger and calamity from their family. There is a special yearly feast "Alom Mmuo" in honour of all ancestors (Arinze, 1967, p. 20). Ancestors do come back to commune with living descendant seasonally. the Igbos recognize the presence of ancestors during "Igwa ali" festival (Aja, 2001, p. 51). Special sacrifice is made to the earth goddess. Food is served to the ancestors who are called upon, to come and commune with the living descendants according to their order of seniority.

In Igbo traditional thought, ancestors and earth goddess (Ani) are the custodians of public morality. Ancestors can cause trouble if there are some violations of community laws (Mbiti, 1969, p. 163). But, for the Yorubas; ancestors come back during Egungun festival to warn their living descendant on morality. The head of kindred (umunna) in Igboland holds the "ofo" which is the symbol of authority that represents the ancestors and forms the link with them.

\section{Reincarnation}

Reincarnation is a belief that souls of the dead come back again to live in a new body. The soul is imprisoned in the body as a form of punishment (Jowett, 1953, p. 386). Those who lived bad live in the past; their souls were imprisoned in the body of lower animals. In African traditional thought, the spirit of ancestors remains in the state of personal immortality for about four to five generation during which he can partially be reincarnated in a new born child (Mbiti, 1969, pp. 118-119). After that period, when nobody among the living remembers him by naming children after him or pouring libations; it becomes a ghost of unknown person. When a parent wishes to find out which of the ancestors has returned, he goes to a fortune teller and name all the ancestors. The fortune teller chooses from the list the returned one (Arinze, 1967, p. 17).

The Igbo belief in reincarnation is an indication that the soul never dies. Parents give their children the names of their good ancestors. Bad progenitors never return. So, the Igbos believe that people have been born again of the same or another mother. Children who die young are believed to have dedicated beforehand in their group when they would die, especially if they do not like the family. Such children are regarded as "ogbanje” (repeaters).

Another evidence of reincarnation is found in the practice of masquerade (Mmanwu). Masquerades according to Igbo belief, represent images of our dead relatives coming from the world beyond to the earth for one reason or the other which they disappear (Ogbukagu, 1997, p. 91). Masquerades are believed to be the dead who come back to life for special celebration like festivals and celebrations of final funeral rites.

\section{Evaluation}

In Igbo traditional thought, life, death and after death share a mutual harmony which completes a full cycle of authentic human existence. Is there a reality after death? Although life after is conceived to enhance and promote good fortunes in the community, there may not be enough evidence to verify the reality of the metaphysical claims of the spirit world and the role of ancestors in watching over and bestowing good fortunes to their families. The impact of ancestors in life after death can be classified under mere belief which is quite different from knowledge. Belief is based on assumption which can be superstitious. But, there is the need to subject the Igbo metaphysical assumptions to critical examination in order to justify them. This is because knowledge is "a justified true belief based on conclusive evidence".

The undue over reliance of Africans on metaphysical worldview is an impediment to critical thinking and 
invention. The effort which can be channeled to inventing useful things in the society is diverted in making sacrifices to gods, deities and ancestors. This futile venture may explain why Africa is behind other continents in terms of techno-scientific development. African deterministic world views promote laxity in the society. Hence, there is no need of human effort since sacrifices to gods and ancestors enhance good fortunes and success in life. But, the sciento-technical progress is not possible on mythico-religious assumption of the world. Tremendous sciento-technological breakthrough was not made in Europe until the hard grips which religion had on them during the medieval era gave way to the humanism of enlightenment (Boas, 1962, p. 18). Thus, the application of scientific method during the enlightenment to regulation of human affairs refuted dogmas and dispelled ignorance and superstition.

On the other hand, Igbo conception of death and after death tends to promote idealist theory of death. It is evident in idealist theory of death that spiritual realm controls the physical. In this regard, death is integrated as final phenomenon of life, which becomes part of life itself. Contrary to this view point, realists conceive death as the door leading man into the realm of non being. In this line of thought, the advantage of interiorizing death which serves our own ends and the undeniable of truth which they include should not mislead us (Sartre, 1956, p. 533). Thus, the realists' conception of death as an exit into the realm of non being accounts for deep mourning and grief associated with death in human society.

\section{Conclusion}

Death is an inescapable fact of human existence. To deny totally the authenticity of Igbo conception of death and life after death implies throwing away the baby with the bath water. African belief in life after death highlights the spiritual dimension of life which serves to promote the authentic existence of individual. Man is a composite of spirit and body. Death makes human beings realize that earthly sojourn is a destination to the life beyond.

\section{References}

Aja, E. (2001). Metaphysics: An introduction. Enugu: Donze Publishers.

Arinze, F. A. (1967). Sacrifice in Igbo religion. Ibadan: Ibadan University Press.

Basden, G. T. (1982). Among the Ibos. London: Frank Cass and Co. Ltd.

Boas, M. (1962). The scientific renaissance: 1450-1630. New York: Harper \& Row Publisher.

Donnel, W. (1931). Religion and morality among the Ibos of Southern Nigeria. Primitive Man, 4, 56.

Heidegger, M. (1973). Being and time. Oxford: Basil Blackwell.

Hornby, S. (2000). Oxford advanced learner's dictionary. Oxford: Oxford University Press.

Jowett, B. (1953). The Dialogue of Plato. Oxford: Clarendon Press.

Koestenbaun, P. (1964). The vitality of death. Journal of Existentialism, 5, 139-166.

Maduabuchi, R. O. (2009). Suicide in Albert Camus existentialist philosophy (M.A. dissertation, Department of Philosophy, University of Nigeria, Nsukka).

Magesa, L. (1997). African religion: The moral tradition of abundant life. Nairobi: Pauline Publications.

Mbiti, J. (1969). African religion and philosophy. Nairobi: East African Educational Publishers Ltd.

Mbiti, J. S. (1975). Introduction to African religion. Nairobi: East African Educational Publishers Ltd.

Ogbukagu, I. N. (1997). Traditional Igbo belief and practices. Owerri: Novelty Industrial Enterprise Ltd.

Omoregbe, J. I. (1991). A simplified history of Western philosophy (Vol. 3): Contemporary philosophy. Ikeja: Joja Educational Research and Publishers.

Sartre, J. P. (1956). Being and nothingness. London: Menthuen Press. 